\title{
Phosphorus Governance within Planetary Boundaries: The Potential of Strategic Local Resource Planning in The Hague and Delfland, The Netherlands
}

\author{
Lisa Harseim ${ }^{1, *}$, Benjamin Sprecher ${ }^{2}\left(\mathbb{C}\right.$ and Cathrin Zengerling ${ }^{1}(1)$ \\ 1 Faculty for Environment and Natural Resources, Albert-Ludwigs University Freiburg, \\ 79106 Freiburg, Germany; cathrin.zengerling@enrlaw.uni-freiburg.de \\ 2 Faculty of Industrial Design Engineering, Delft University of Technology, \\ 2628 CE Delft, The Netherlands; b.sprecher@tudelft.nl \\ * Correspondence: lisa.harseim@enrlaw.uni-freiburg.de
}

check for updates

Citation: Harseim, L.; Sprecher, B.; Zengerling, C. Phosphorus Governance within Planetary Boundaries: The Potential of Strategic Local Resource Planning in The Hague and Delfland, The Netherlands. Sustainability 2021, 13, 10801. https://doi.org/10.3390/ su131910801

Academic Editor: Antonio Boggia

Received: 30 August 2021

Accepted: 18 September 2021

Published: 28 September 2021

Publisher's Note: MDPI stays neutral with regard to jurisdictional claims in published maps and institutional affiliations.

Copyright: (c) 2021 by the authors. Licensee MDPI, Basel, Switzerland. This article is an open access article distributed under the terms and conditions of the Creative Commons Attribution (CC BY) license (https:/ / creativecommons.org/licenses/by/ $4.0 /)$.

\begin{abstract}
In recent years, a growing body of research has explored the urban dimension of the critical resource phosphorus with a focus on urban metabolism analysis, recovery technologies and governance frameworks. However, there has been no tangible and holistic attempt at choosing between available measures and instruments for their implementation in the urban realm. With the growing and increasingly urban world population, cities have become more and more important as actors in phosphorus governance by fueling global phosphorus flows, e.g., via the consumption of food, agricultural products, and phosphorus recycling. Globally, a future-proof phosphorus metabolism may be contributed to by strategic local phosphorus planning. This article systematically explores the purposive potential of local phosphorus planning using a case study of The Hague, The Netherlands. Looking across multiple administrative and spatial dimensions, the study combines quantitative analysis of phosphorus flows with qualitative investigation of their drivers, the actors involved, current regulations and local scope for action. The research reveals the feasibility of meaningfully impacting phosphorus flows through urban action. The potential for strategic local resource planning is demonstrated in a grid of policy options and in the assessment of their socio-economic and environmental benefits. Additionally, the study draws up a list of key recommendations to transfer to other urban settings. It encourages further research aimed at closing data gaps for local phosphorus inventories, collaborative approaches in strategic resource planning, scope for action in other cities or jurisdictions, as well as improved quantification of the outreach of policy effects.
\end{abstract}

Keywords: strategic resource planning; urban phosphorus governance; phosphorus flow analysis

\section{Introduction}

The absence of effective (inter)national phosphorus governance mechanisms lends greater weight to local initiatives [1,2], but cities generally do not take a strategic approach when considering this irreplaceable nutrient. Cities are recognized as key actors in global change via local action under global environmental governance processes, such as those established via the Paris Agreement regime or the Sustainable Development Goals (e.g., in SDG 11-Make cities and human settlements inclusive, safe, resilient and sustainable [3]). Cities are increasingly aware of their environmental weight, as well as the vulnerability of their infrastructures and inhabitants' lifestyles. Therefore, more and more cities are developing their own local strategic action plans that target global challenges. To date, these strategic action plans focus mainly on the fields of climate change and-at a less advanced stage- the circular economy.

Cities play an important role, not only in the case of climate change, but also in terms of phosphorus flows, due to their emissions and the nutrient releases they drive elsewhere. Industrialized agriculture that feeds the world's cities accounts for more than $90 \%$ of 
the 2011 phosphorus boundary [4]. According to the planetary boundaries introduced by Rockström et al. (2009), updated in 2011, 2015, and 2018 [5-8], current phosphorusdriven eutrophication far exceeds the limit value for flows from erodible soils to freshwater (6.2 Mt/yr [8]), and can be expected to increase further [4].

The food demand of the growing urban population is vulnerable to phosphorus scarcity, as this directly affects the affordability and availability of food supply. Nowadays, urban resource flows increase food system vulnerability by simultaneously fueling linear phosphorus withdrawal from agricultural soils and encouraging excessive phosphorus emissions into waters. Demand for phosphorus fertilizer is projected to increase by nearly $400 \%$ by 2050 [9]. This exacerbates the challenge of possible scarcity, given the uncertainty in reserve longevity estimates [10-12].

A growing body of research explores the urban dimension of phosphorus flows in a variety of cities in Europe and beyond (see [13-16]) but the "how" of governing these flows from the urban perspective remains unclear. Research on phosphorus governance identified a lack of effective governance measures across different levels that could provide a coordinative umbrella framework, leading to systematic interventions against key drivers of business-as-usual processes [11,17-20].

To fill this gap, we explored the improvement potential that strategic phosphorus planning at the local level could offer. Borrowing from Circular Economy and Climate Action Planning, we contend that such strategic action plans should consist of mid- and long-term targets, a set of measures to reach those targets, and a monitoring and review mechanism. They should be updated in regular policy cycles. Ideally, these plans should be based on thorough inventories - knowledge of the urban metabolism - in order to inform the design of measures and their evaluation.

In a case study approach, we selected The Hague and the surrounding Delfland region to investigate whether a city has the power to alter local phosphorus flows towards a future-proof global phosphorus metabolism. On the one hand, the highly urbanized area in a Western European jurisdiction was chosen for its high dependency on phosphorus imports for an agricultural sector of international importance. On the other hand, the region presents a significant local scope for action in terms of self-administration.

With a holistic attempt, grounded in a real-world context, we were able to reliably conclude that strategic local resource planning is feasible. It has the potential to meaningfully impact phosphorus flows through urban action. Based on an in-depth understanding of the socio-economic and environmental factors across different levels, we compiled a detailed list of appropriate improvement measures and assessed their viability for implementation. Over two years (2018-2019), the study examined the potential of local strategic planning responses to eutrophication risks and scarcity-induced food security threats. We found that public actors on the local level can directly impact phosphorus flows in the present and future through an overarching strategic plan.

\section{Materials and Methods}

We explored the potential of local strategic phosphorus planning in a multi-level, three-step research design. The integration of the interdisciplinary mix of methods in this research approach is shown in Figure 1.

A shortcoming of common urban metabolism studies is their geographic and temporal limitations [21]. While they further the understanding of the urban phosphorus flows in different contexts, the system boundaries in the study are generally limited to local administrative borders. This leads to a neglect of phosphorus inputs in global hinterlands where they are required for food production to satisfy local demands.

In response to this methodological gap, we considered every level, from the local to the global, in each step of our analysis. In this way, we integrated spatial and temporal boundaries that cross different levels.

We condensed learnings on the potential of strategic local phosphorus planning from the multi-level information by classic policy design in two steps. These learnings follow 
Weimer and Vining's (2005) [22] method of problem and solution analysis, supported by the work of Pica-Camarra (2009) [23], and Birkland (2016) [24].

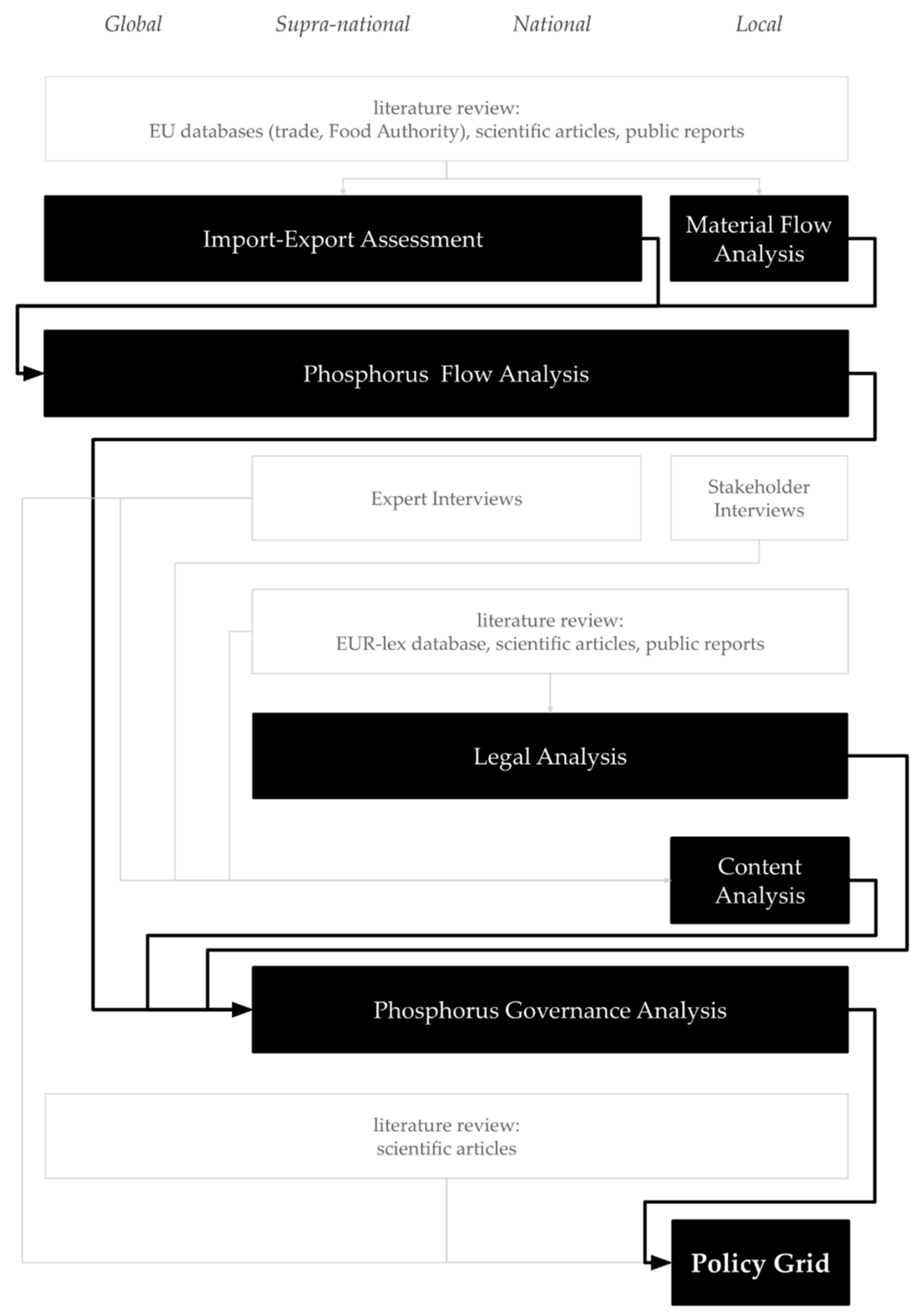

Figure 1. Research design elements of the phosphorus governance analysis required to delineate the potential of strategic local phosphorus planning.

The first step builds a thorough understanding of the factors shaping local phosphorus metabolism in a comprehensive phosphorus governance analysis. For this, we built as complete as possible an inventory of resource flows, supplemented by science-backed computations in order to bridge gaps in reporting. This information can be used in the policy cycle for reevaluation. In the following step, solution analysis, these factors are assessed in order to delineate the frame of action for local policy. We depicted this result in a policy grid to create policy alternatives in line with the overall goal set by the problem 
framework. These alternatives comprise packages of measures to adjust regional flows and are subject to a plan for suitable modes of governance for their implementation.

For a holistic phosphorus governance analysis, the study combines interdisciplinary quantitative and qualitative research methods. The quantitative analysis expands the narrow, local system boundary to the wider, global context. A local material flow analysis for phosphorus carriers is complemented by a simplified import-export assessment of phosphorus in food products transported to and from The Netherlands. The resulting phosphorus substance flow analysis (SFA) was plotted in the software STAN 2.0 in relation to the case study area, The Hague and Delfland, based on their administrative boundaries. This allowed exploration of the potential impact of local phosphorus planning on the ground. Additionally, it enabled understanding of its significance for upstream phosphorus requirements during production, the overall stock building within the country or resource extraction, depending on the trade balance.

Legal and content analysis contributed the qualitative aspects required to interpret the quantitative depiction of the status quo, thereby outlining the frame of action of local public governance. The legal analysis shed light on the governance framework created by regulatory conditions and the stakeholders involved. The analysis took stock of available capacities and maps relevant key actors. The institutional design of the policy can build on this governance information for the distribution of tasks across suitable authorities and build bridges for collaboration where their fulfillment requires a crossing of departmental remits. The content analysis was adjusted for phosphorus by investigating the social, ecological, and technical flow factors that are presented by Metson et al. (2015) [15].

The legal analysis builds on a literature review of primary and secondary sources, including legislative acts relevant for the case study, from Europe-wide to the local level. The content analysis integrates semi-structured expert and stakeholder interviews. The content analysis follows the approach developed by Mayring (2013) [25]. Its coding system and interview topic guides follow the factors presented by Metson et al. (2015) [15] Experts and stakeholders were selected via snowball sampling following Gläser and Laudel (2010) [26]. In total, 15 interviews with an average duration of one hour were conducted.

Substance flow analyses require high data input and gaps in reporting made flow quantification difficult. These difficulties arose because not all actors involved and identified in the interview process could be addressed. Additionally, private sector actors were found not to be approachable or transparent. Data related to overlapping or unassigned administrative boundaries but were adjusted in relation to the case study area and filled with population-based calculations utilizing flow properties (Table 1). Despite initial difficulties in reconciling the reported and computed values, the model could be validated by the STAN software, and the results are partly confirmed in similar quantities in comparable literature, e.g., the nearly equal phosphorus content in wastewater and solid waste flows identified in Gothenburg [27].

Table 1. Overview of data sources for the substance flow analysis ordered according to their reliability (top $=$ most reliable, bottom $=$ least reliable; $\mathrm{P}=$ phosphorus). Where several data sources had to be combined to extrapolate the 2019 annual flows, multiple years of data sources are listed.

\begin{tabular}{cll}
\hline Data Source & Factors Considered & \multicolumn{1}{c}{ Resulting Flows } \\
\hline & & river water $(2019,2015)$ \\
& & groundwater outflow (2017) \\
& & reverse osmosis (2017) \\
Publicly Commissioned by & effluent (2017) \\
Local Authorities & reported P quantities & sewage-free leakage \\
& & urban rainwater run off (2017) \\
& & brackish water (2017) \\
& North Sea (2017) \\
\hline
\end{tabular}


Table 1. Cont.

\begin{tabular}{|c|c|c|}
\hline Data Source & Factors Considered & Resulting Flows \\
\hline Local Public Authorities & reported P quantities & $\begin{array}{l}\text { sewage }(2017,2019) \\
\text { sludge }(2017,2019) \\
\text { effluent }(2017,2019) \\
\text { bottom ash }(2017)\end{array}$ \\
\hline $\begin{array}{l}\text { Local Public Authorities x } \\
\text { Local Water Provider }\end{array}$ & $\begin{array}{l}\text { reported material flow } \mathrm{x} \\
\text { reported } \mathrm{P} \text { concentration }\end{array}$ & drinking water $(2017,2019)$ \\
\hline $\begin{array}{l}\text { Local Public Authorities x } \\
\text { peer-reviewed literature }\end{array}$ & $\begin{array}{l}\text { reported material flow x } \\
\text { literature-based } \mathrm{P} \\
\text { concentration }\end{array}$ & $\begin{array}{l}\text { organic waste }(2012,2015) \\
\text { mixed waste }(2018,2015)\end{array}$ \\
\hline $\begin{array}{l}\text { Local \& European Public } \\
\text { Authorities x } \\
\text { peer-reviewed literature }\end{array}$ & $\begin{array}{l}\text { reported population } \mathrm{x} \\
\text { literature-based diet \& } \mathrm{P} \\
\text { concentration }\end{array}$ & food \& drink $(2018,2014)$ \\
\hline $\begin{array}{l}\text { National Statistics Office x } \\
\text { peer-reviewed literature }\end{array}$ & $\begin{array}{c}\text { reported area } \mathrm{x} \\
\text { literature-based } \mathrm{P} \\
\text { consumption/vegetable } \\
\text { output }\end{array}$ & $\begin{array}{l}\text { fertilizer }(2015,2019) \\
\text { produce }(2019)\end{array}$ \\
\hline $\begin{array}{l}\text { National Public Authorities x } \\
\text { peer-reviewed literature }\end{array}$ & $\begin{array}{c}\text { reported population } \mathrm{x} \\
\text { literature-based diet \& } \\
\mathrm{P} \text { concentration } \mathrm{x} \\
\text { literature-based food-waste } \\
\text { losses }\end{array}$ & $\begin{array}{l}\text { food \& drink import (2019, } \\
\text { 2014) }\end{array}$ \\
\hline $\begin{array}{l}\text { Own calculation x European } \\
\text { Public Authority }\end{array}$ & $\begin{array}{c}\text { preceding } \mathrm{P} \text { flow } \mathrm{x} \\
\text { data-based } \mathrm{P} \text { concentration }\end{array}$ & compost $(2013,2019)$ \\
\hline $\begin{array}{c}\text { Own calculation x National } \\
\text { Statistics Office }\end{array}$ & $\begin{array}{l}\text { preceding P flow } \mathrm{x} \\
\text { data-based shares } \\
\text { of produce }\end{array}$ & $\begin{array}{l}\text { produce export (2019) } \\
\text { produce domestic (2019) }\end{array}$ \\
\hline $\begin{array}{l}\text { Interviews, public } \\
\text { information }\end{array}$ & no numerical data available & $\begin{array}{l}\text { residual solid waste (2019) } \\
\text { mixed high-calorific waste } \\
(2019) \\
\text { organic residual waste (2019) } \\
\text { bottom ash (SW) (2019) } \\
\text { digestate (2017) } \\
\text { reverse osmosis (2017) }\end{array}$ \\
\hline
\end{tabular}

Not all organic or industrial flows that contribute to phosphorus transport could be accounted for. We focused on phosphorus in food-related flows destined for direct human consumption, due to their relevance for urban food security and food system resilience. Other biomass flows (e.g., wood in construction materials, cardboard, or paper) have been omitted from the assessment. More specifically, the food flows for the local SFA and its expansion were calculated by combining the average Dutch diet composition published by van Dooren et al. (2014) [28], with phosphorus concentrations provided by the European Food Safety Authority and the trade statistics of respective food groups and trading countries listed in the official European Market Access Database. Overall, the study was conducted on the basis of 2018 and 2019. It integrated interviews from 2018 with previous and subsequent reports, relevant for flow quantities and policies. The data used in this multi-level research approach has been verified whenever possible by cross-checking the information with various sources.

\section{Results}

Qualitative and quantitative analysis together show the impact potential of and responsibility for local strategic phosphorus planning. Both potential and responsibility become clear as a result of the expanded phosphorus flow analysis. Considering the typical 
Dutch diet and its import requirements, stocks of phosphorus build within the Netherlands, while trade withdraws phosphorus from agricultural production countries (3.1. Inventory of Flows: Phosphorus Flow Analysis with Import-Export Expansion). Accordingly, the local substance flow analysis reveals the impact potential via relevant phosphorus flows in local food production, consumption, and trading. Instead of a return of nutrients to their origin, local wastewater and waste streams disperse major quantities into sinks.

The qualitative analysis of European and Dutch laws and policies identifies gaps in comprehensive phosphorus governance and early efforts to fill such gaps, currently advancing the legal context (3.2. Review of Phosphorus Relevant Laws and Policies). Since, in The Netherlands, regional water boards play a crucial role in governing (waste-) water streams, strategic local phosphorus planning potential lies not only in the city of The Hague but also in the surrounding region of Delfland.

Merging phosphorus flow analysis and legal analysis against the backdrop of the context analysis results in holistic knowledge of the local phosphorus flows and their governance. A policy grid links concrete measures to phosphorus flows in wastewater, waste, food production, and trading (3.3. Phosphorus Governance Analysis: A Policy Grid for Local Strategic Phosphorus Planning). All measures can be implemented within the local scope for action via regulation and other modes of governance. The set of targeted measures and available modes for their implementation outlines the wide window of opportunity for strategic local phosphorus planning.

\subsection{Inventory of Flows: Phosphorus Flow Analysis with Import-Export Expansion}

The comparison of food-borne phosphorus imports and exports to and from The Netherlands required for typical Dutch consumption reveals phosphorus gains for The Netherlands and losses for most trading partners (see Table 2).

Table 2. The virtual phosphorus in- and outflows of The Netherlands (out of EU-28), calculated from the average $\mathrm{P}$ concentrations in the typical Dutch diet (left = imports, right = exports).

\begin{tabular}{cccc}
\hline $\begin{array}{c}\text { Total P Trade } \\
\text { Balance } \\
\text { in Tonnes }\end{array}$ & Countries Exporting to NL & $\begin{array}{c}\text { Total P Trade } \\
\text { Balance } \\
\text { in Tonnes }\end{array}$ & $\begin{array}{c}\text { Countries Exported } \\
\text { to from NL }\end{array}$ \\
\hline $11,989.81$ & United States & -0.08 & Mali \\
7472.76 & Brazil & -0.11 & Central African Republic \\
4423.97 & Ukraine & -0.16 & Thailand \\
3762.90 & Ivory Coast & -0.30 & Afghanistan \\
2144.68 & Paraguay & -0.31 & Pakistan \\
1322.41 & Ghana & -0.36 & Trinidad \& Tobago \\
1313.03 & Argentina & -0.50 & Kenya \\
1059.16 & Australia & -0.54 & Morocco \\
873.19 & Canada & -0.77 & Egypt \\
826.34 & Cameroon & -1.07 & Taiwan \\
821.35 & Nigeria & -1.19 & Iran \\
655.72 & Uruguay & -1.44 & Cape Verde \\
270.97 & Moldova & -1.71 & Ceuta \\
258.87 & Ecuador & -2.07 & Republic of Korea \\
246.50 & Sierra Leone & -3.78 & Mexico \\
183.29 & Peoples Republic of China & -4.73 & Iraq \\
102.49 & Indonesia & -5.30 & Liechtenstein \\
97.76 & Peru & -5.53 & Jordan \\
97.06 & Liberia & -8.10 & Israel \\
83.98 & Iceland \\
28.00 & Domican Republic & -8.75 & Serbia \\
5.31 & Myanmar & -12.80 & Lebanon \\
4.85 & New Zealand & -54.18 & Oman \\
0.30 & India & -75.32 & Norway \\
\hline
\end{tabular}


Table 2. Cont.

\begin{tabular}{|c|c|c|c|}
\hline $\begin{array}{c}\text { Total P Trade } \\
\text { Balance } \\
\text { in Tonnes }\end{array}$ & Countries Exporting to NL & $\begin{array}{c}\text { Total P Trade } \\
\text { Balance } \\
\text { in Tonnes }\end{array}$ & $\begin{array}{l}\text { Countries Exported } \\
\text { to from NL }\end{array}$ \\
\hline 0.17 & Malaysia & -76.42 & Singapore \\
\hline 0.03 & South Africa & -91.40 & Qatar \\
\hline \multirow[t]{9}{*}{-} & Niger & -119.65 & Kuwait \\
\hline & & -123.02 & Russian Federation \\
\hline & & -210.06 & Saudi Arabia \\
\hline & & -211.09 & Algeria \\
\hline & & -228.33 & Turkey \\
\hline & & -270.66 & Switzerland \\
\hline & & -311.08 & Hong Kong \\
\hline & & -391.43 & Japan \\
\hline & & -451.46 & United Arab Emirates \\
\hline $38,044.87$ & $\begin{array}{l}\text { total P imported to NL via } \\
\text { food trade }[\mathrm{t}]\end{array}$ & -2750.02 & $\begin{array}{l}\text { total } P \text { exported from } \mathrm{NL} \\
\text { via food trade }[\mathrm{t}]\end{array}$ \\
\hline
\end{tabular}

Most of the greenhouse produce that is characteristic of the case study region is not a major part of the Dutch diet according to van Dooren et al. (2014) [28] and is destined for export. Local food consumption is mostly covered by imports. By taking phosphorus concentrations and data on trade in these diet-specific food items, a phosphorus balance can be calculated.

On a national scale, this results in an overall surplus of about $0.035 \mathrm{Mt} \mathrm{P} / \mathrm{yr}$ remaining in The Netherlands. This is partly the result of the calculation basis of domestically required food imports. Little of the same food groups is exported. This shows the limited suitability of input-output analyses for tracing complex global food trade and for phosphorus flow systems. Additionally, the trade database categories do not match the diet categories very well. The trade database does not allow for a clear-cut separation between food products destined for direct human consumption and animal feed. This means that the import and export calculation contains not only the phosphorus imported for human consumption in the Netherlands but is inflated by the needs of the Dutch livestock sector. This sector's productivity exceeds domestic demand and the exported phosphorus does not balance the imports in an assessment from the perspective of the national diet.

However, the diet-based trade assessment shows the magnitude of phosphorus stockbuilding in The Netherlands. In the absence of extensive nutrient recycling, the country can be seen as a sink. The loss is a resource extraction from the food supplier countries with the largest amounts of phosphorus being imported via food and fodder from the United States and Brazil. In the constant need to replenish their agricultural soils, these food suppliers increase the demand for phosphate rock mining through global fertilizer trade with environmental and socio-economic repercussions. Cities where end consumers of this food trade are concentrated bear a share of responsibility, as well as impact potential, in this linear system. The Hague and the Delfland region account for about a fifth of the food consumption-based trade balance with $0.0015 \mathrm{Mt} \mathrm{P} / \mathrm{yr}$ (Figure 2).

Aside from food consumption, regional food production for trade is a major node in the local phosphorus system due to highly industrialized horticulture. The greenhouses covering a huge expanse in the west of the Delfland region operate in an almost closed system. They draw water from the aquifer via reverse osmosis for controlled growing conditions. High-tech fertilizers are added for precise control of the nutrient flows among the plants and effluents are filtered. Overseen by the water authority, run-offs from food production are well-monitored. Despite filtering, the reported phosphorus content of agricultural effluent pollutes channels and the environment, and remains a constant challenge for farmers and the water authority. 


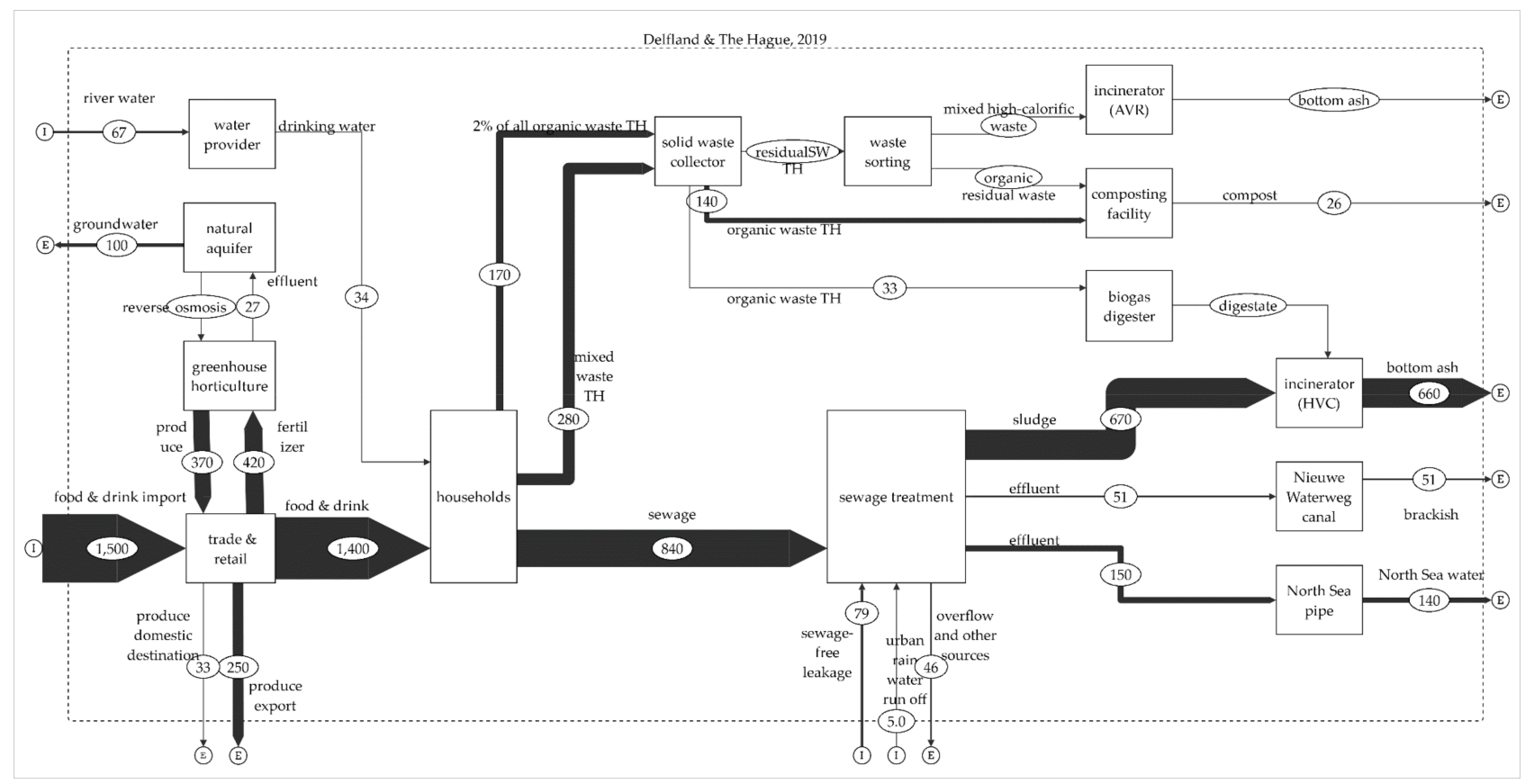

Figure 2. Overview of the combined phosphorus flows of the Delfland region and The Hague in 2019. Flows marked with " $\mathrm{TH}^{\prime}$ refer to the city of The Hague only and can be tripled to match the scale of the sewerage for the Delfland region. All values in $\mathrm{t} P / \mathrm{yr}$.

Regionally, the substance flow analysis of the case study area (see Figure 2) shows that the phosphorus-carrying flows from The Hague and Delfland need to be addressed strategically as one system, as their infrastructure is highly interconnected. This supports water-based phosphorus management efforts but comes with a challenge. The Delfland region benefits from an efficient water infrastructure with less than $10 \%$ leakage. Yet, in the case of storm water events, overflows release unfiltered sewage water into the environment. Due to the mixed sewer system in most of The Hague, sewage treatment plants receive about a 30\% more blackwater on those occasions which partly has to be released untreated.

Particularly relevant for this case study are the opposing effects of the flood protection infrastructure. On the one hand, the old dykes bordering the case study region slowly but constantly leach phosphorus into the aquifer, requiring constant pumping with no natural outlet for phosphorus entering Dutch freshwaters. On the other hand, the dykes disconnect the surrounding lands from the nutrient loads emitted upstream in the rivers Rhine and Meuse.

These rivers are the source of The Hague's, and about half of Delfland's, drinking water supply, importing phosphorus into the system even after precipitation during the purification process. The biggest mass flow, with 66 billion liters of river water, could be mistakenly seen as a major flow in the system, but it contains only low amounts of phosphorus, resulting in a comparatively insignificant substance quantity. Effluents from the sewage treatment plants are subject to strict limit values set by the water authority for the purpose of minimizing the environmental burden. However, due to the magnitude of this material flow, the absolute phosphorus emissions into the North Sea or the estuary of the River Meuse are significant.

The regional water authority and related private actors realized the potential in waterborne phosphorus flows and attempt to tap it. They implemented the first steps towards nutrient recycling at three points: purification of drinking water, sewage treatment plants, and incineration of sludge. Firstly, the drinking water company for half of Delfland and all of The Hague (Dunea) uses iron-sand to bind and reduce the phosphorus levels in water drawn from the rivers. This product is used experimentally to fertilize nearby tulip fields. Secondly, the sewage treatment plants precipitate struvite in the sludge to avoid clogging in the pipe infrastructure as a common practice and to minimize maintenance costs [29], but 
struvite has potential utility as a slow-release fertilizer. Thirdly, a trial is being conducted by the company EcoPhos into transporting sewage sludge incineration ash to Dunkirk (France) for the recovery of phosphorus to produce fertilizer. Thus far, the incineration ash of both sewage sludge and solid waste may be used as road filling, locking $90 \%$ of this flow's nutrients in local sinks. The water authority supports the EcoPhos business case by increasing the concentration of phosphorus in the ash they receive.

Tapping the potential of solid, organic wastes proves to be more challenging than the recovery from wastewater due to the lack of accessible data on the solid waste flows in the private sector. The high rate of privatization spreads responsibilities across various actors and renders the waste sector as lacking in transparency and challenging to approach. Since there is no obligation to publicly report the output of incineration, sorting, and composting facilities outside of the municipal waste collection system and attempts to contact private companies were unsuccessful, phosphorus flows in the privatized system could not be fully quantified.

To utilize the organic waste, the city of The Hague collects bread as a separate waste stream for biogas production. The product must be subsidized in order to be competitive and fed into the gas grid. The collection rate for organic solid waste from households in the city is exceptionally low (about $2 \%$ ) compared to the low-ranging average of organic waste collection countrywide (10\%). Companies are free to select a private contractor to dispose of their solid waste. In 2019, the AVR company was contracted to operate a waste sorting facility to single out high-calorific waste for incineration, but there was no mention of the share of the organic fraction.

Figure 2 visualizes the solid waste flows for The Hague only, due to the municipalities' individual and decentralized authority for waste management. Delfland comprises three municipalities that each manage their waste autonomously. The Hague has roughly one third of the population of the Delfland region. The phosphorus potential in solid household waste in the Delfland region as a whole can be estimated at three times the amount shown in Figure 2. The phosphorus content in organic solid waste is, therefore, likely to be about equal to or even in excess of the amount transported in sewage. This opens up opportunities for innovative, locally embedded ways of nutrient recycling, for example by increasing the rate of organic waste collection and introducing a new treatment method such as fermentation.

\subsection{Review of Phosphorus Relevant Laws and Policies}

The governance of phosphorus flows in Delfland and The Hague is embedded in a multi-level legal framework ranging from local to European (see Figure 3). Currently, most European, or Dutch phosphorus regulation that affects the local situation aims to protect water bodies from eutrophication. It does not deal with concerns of scarcity, food security or environmental justice. The legislation in question is the EU Water Framework Directive (WFD), the Nitrate Directive (ND), the National Emission Ceiling Directive (NECD), the Groundwater Directive (GD), the Marine Strategy Framework Directive (MSFD), the Industrial Emissions Directive (IED), the Urban Wastewater Directive (UWWD), and the Sewage Sludge Directive (SSD) [30-32]. At the Dutch federal level, instigated in part by the EU regulation, it comprises the Dutch Phosphorus Reduction Decree, the Manure and Fertilizer Act and the Soil Protection Act. Soon, the revised Circular Economy Action Plan will be an integral part of the regulatory context in the EU.

A central steering instrument of this legislative framework are River Basin Management Plans (RBMP), established under the EU Water Framework Directive and corresponding Dutch legislation. Linking both Marine and Urban Wastewater Directives, these plans address eutrophication issues based on river catchment areas. The most relevant RBMP in the case study area applies to the Rhine, extending over the administrative boundaries of Switzerland, France, Luxembourg, Germany, and The Netherlands. As part of the Delta region, Delfland is subject to packages of measures and limit values while receiving upstream nutrient loads. 


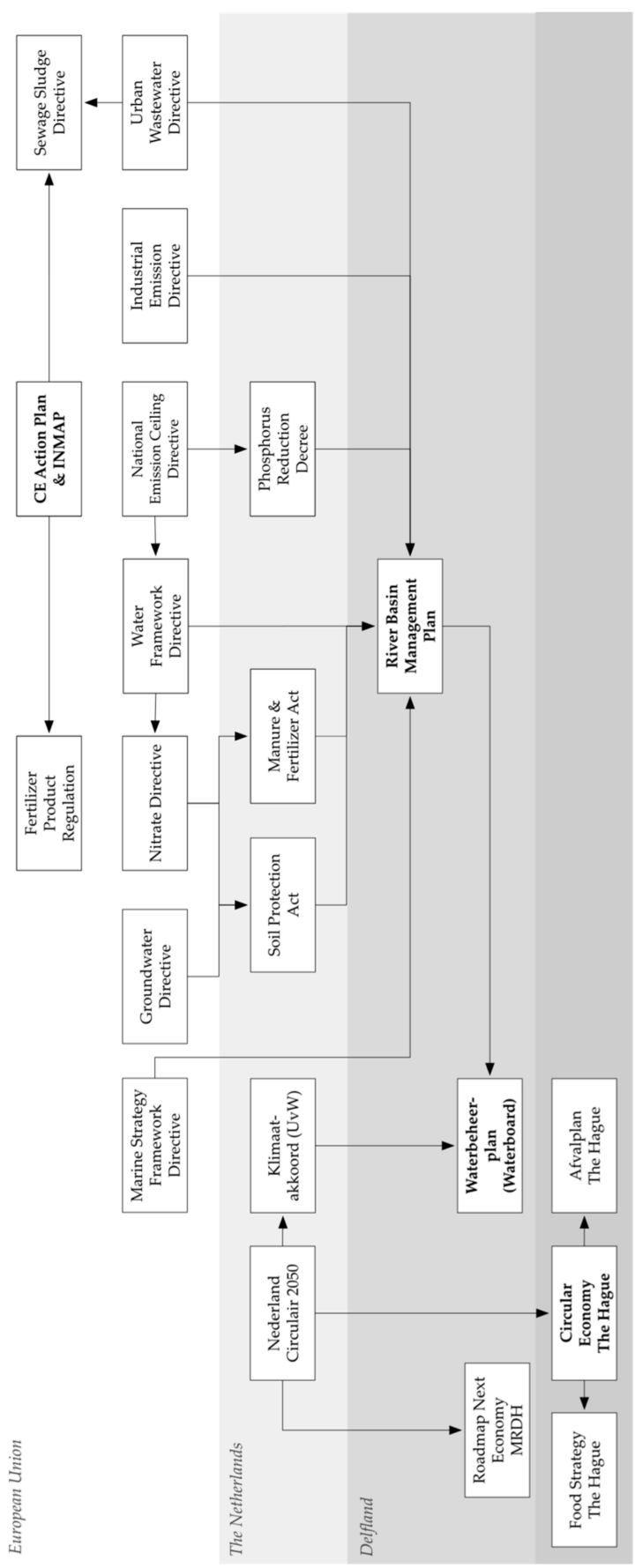

Figure 3. Overview of key legislative and political instruments of the multi-level governance system impacting local phosphorus flows. The instruments are either explicitly linked or affect each other (Dotted $=$ not current but imminent regulation; INMAP = Integrated Nutrient Management Action Plan).

As at European and national level, local policies that affect phosphorus flows are either part of water and soil protection or circular economy governance, but are not coordinated into an overarching plan. For water protection, the most important authorities in The Netherlands are the democratically elected water boards. Their independence is constitutionally enshrined in parallel with the three-tier system of government, but they must comply with provincial by-laws. They are connected to the national government by a working agreement, the 2010 Klimaatakkord, between the Union of Water Boards (UvW) and the Dutch federal government [33], in which the water boards sign up to the Climate and Sustainability Policy of The Netherlands and to cooperation with the Dutch 
River Basin Management in exchange for a national financial budget to cover the costs of the additional efforts required of the water boards.

The key tasks of all water boards are flood protection, sewage treatment and the maintenance of safe waters via strategic plans. These tasks mean that they play a critical role in governing phosphorus flows in the environment and wastewater system. The key steering instruments of water boards are the Waterbeheerplans (water management plans, Figure 3) that are reviewed regularly, based on constant monitoring. Their long- and medium-term goals incorporate the requirements of the relevant RBMPs.

In the case study area, wastewater treatment and the nutrient levels of open waters are managed commonly under the regional water authority. The solid and fluid flows of dewatered sludge and residual, mixed waste recombine in the privatized incineration facility of Dordrecht, in the South of Delfland. In the case of the city of The Hague wastewater flows are under the authority of the Department of City Management, whose responsibilities include the wastewater infrastructure. The administrative boundaries of the Delfland Water Board surround The Hague and cover sewage treatment for about 1.4 million inhabitants.

The municipalities forward the phosphorus load to the water board which is left to apply end-of-pipe solutions to ensure environmental compatibility of the effluents discharged. The link between public and private actors is formed by public-private partnership contracts. Sewage treatment and drinking water supply are provided by the Delfland Water Board and a consortium of international private sub-contractors (i.e., Delfluent in collaboration with HVC).

Circular economy and resource protection in solid phosphorus streams are evident in the case study area in an emerging phase, but they lack the binding regulation that would ensure effective implementation. Top-down motivation from the Nederland 2050 strategy inspired local target setting and creative exploration in the agenda for Circular Economy of The Hague. As a first step, its goals are incorporated into the household solid waste management plan (Afvalplan, Figure 3) that aims to increase waste collection rates. Part of the solid waste collection, including sorting, composting, biogas production, and waste incineration, is carried out for the Municipality of The Hague by a range of private companies.

Influencing phosphorus flows at the local level is often an unintended side effect of related policies. The waste management plan increases recycling potential and, as a side effect, reduces uncontrolled leakage of phosphorus flows. Similarly, The Hague's Food Strategy addresses food security without particular concern for phosphorus. Nevertheless, it affects local substance flows, for example by supporting urban agriculture. Moreover, the Roadmap Next Economy of the Metropolitan region of Rotterdam and Den Haag (MRDH, Figure 3) will impact phosphorus flows by steering economic development towards strengthening the application of regional bio-based innovation. This changes the requirements for local phosphorus demand and the economic conditions for feasible reuse.

\subsection{Phosphorus Governance Analysis: A Policy Grid for Local Strategic Phosphorus Planning}

The phosphorus governance analysis merges information collected during the preceding phosphorus flow, legal, and content analyses (see Figure 1). A key finding of this is the relationship between phosphorus substance flows and adjustment measures to create a framework for strategic local phosphorus policy design (see Figure 4). These measures can be realized via various governance instruments. Derived from the case study of The Hague and the Delfland region, the policy grid is designed to guide policymakers by visualizing path dependencies, cascading impacts, and trade-offs.

Local and regional phosphorus flows in solid waste, wastewater, food and others can be subjected to a range of measures. The list of measures has been generated in response to the identified contextual conditions by synthesizing literature recommendations, authors' expertise, and expert suggestions.

Based on an understanding of the interaction between urban infrastructure and the environment, the measures can be linked to the substance flows mapped for the study area in order to identify the cascading effects of the interconnected structure of the flow 
system. As an example, vegetation-related measures generally take up nutrients and reduce run-off phosphorus loads in water-borne flows or delay their release by buffering in the case of heavy rainfall or flooding events. Vegetation decreases pressure on water infrastructure, affecting every urban water-borne phosphorus flow, as well as waters released into rivers, the sea, and groundwater in a cascade effect. Similarly, solid waste flows see cascading effects that can be utilized for strategic phosphorus action. Measures as simple as an informative waste separation campaign and the distribution of free organic waste collection bags can increase the phosphorus potential for all subsequent actors linked linearly along waste flows.

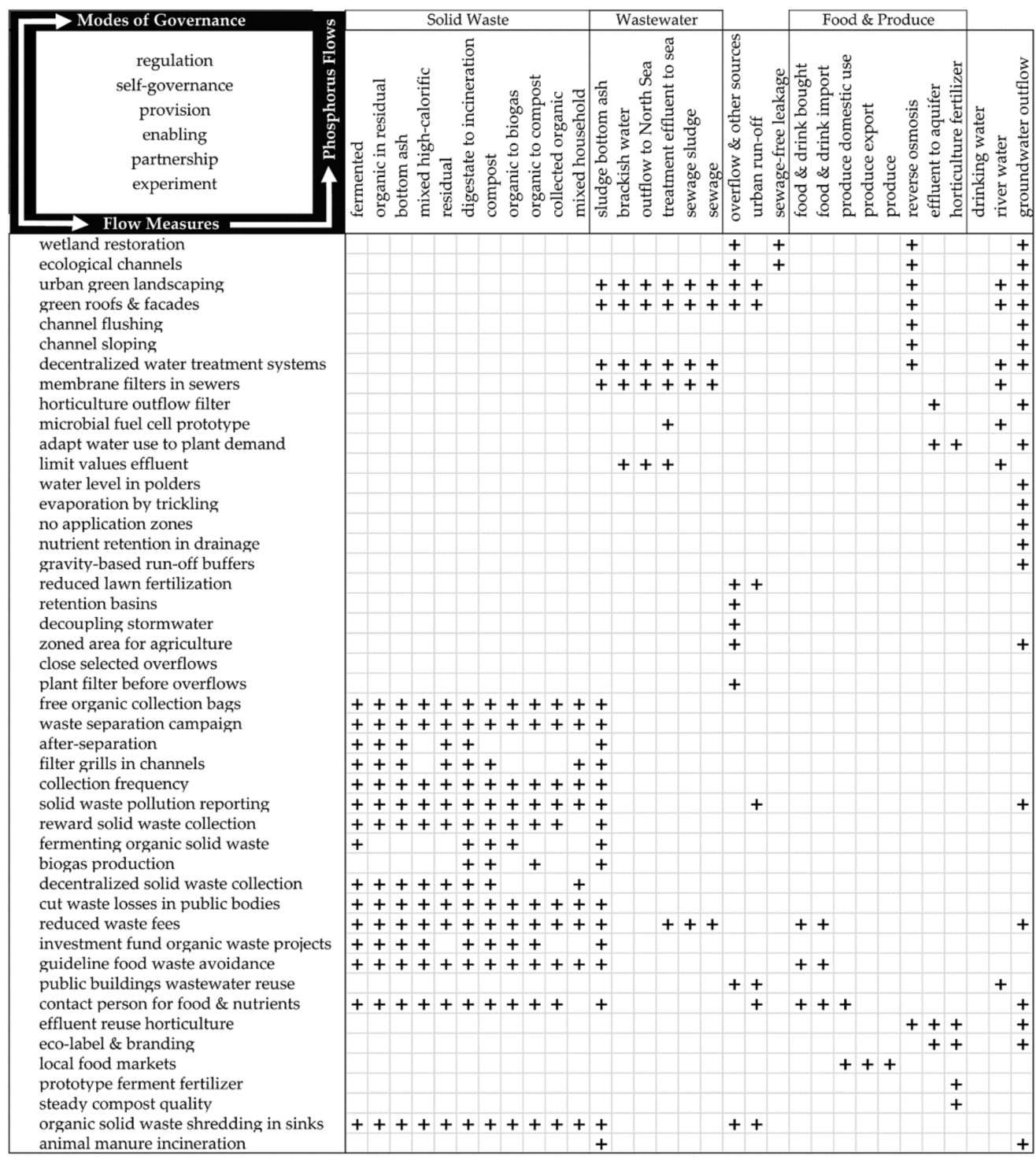

Figure 4. The policy grid for strategic local phosphorus planning: Flows (of Figure 2) can be subjected to adjustment measures under the six modes of governance available to local policymakers.

Considering trade-offs in the cascading flows is essential for effective strategic planning. Measures capturing phosphorus carrier streams at the root source within the region makes their phosphorus potential available for recycling. Phosphorus flows can be intercepted at any later stage of the flow system. They may increase phosphorus concentration or extract and withdraw the substance. This can be utilized to support or unintentionally undermine recycling efforts downstream. 
The combination of applicable modes for implementation of such flow adjustment measures varies greatly, depending on the mandate and scope of the actors involved. The local scope for action is wide and has a mandate to cover measures in the fields mentioned above. The Dutch constitution grants The Hague and all other Dutch municipalities the right to govern their local affairs, including spatial planning, provision of housing, solid waste management, and sewage infrastructure (see article 124, article 128). Hence, the city is responsible for the mixed sewerage, combining black- and rainwater. Local steering instruments can cover a range of modes of governance [34-36]. Accordingly, the six modes are: self-governance, regulation (including urban planning), provision (of infrastructure), partnership, enabling, and experimentation.

As an example of the application of the regulatory mode, the challenges posed by the urban wastewater infrastructure can be counteracted by spatial planning or financial incentives. The mixed sewer system presents a major difficulty for the appropriate dimensioning of sewage treatment facilities run by the water board. Urban and regional spatial planning could encourage greenery to absorb or delay the release of phosphorus in a blue green city approach as advocated by Interreg Europe. Similarly, the city could implement binding regulations that motivate private green investments or reward voluntary contributions. This has been done in the city of Hamburg (Germany), which reduced rainwater collection fees for green roofs, thereby incentivizing retention capacity. Other supporting instruments available to public governance could be the adjusting of the service of park maintenance (i.e., provision mode), citizen information or campaigning for more greenery (i.e., enabling mode), self-governance by green procurement, target setting for increased resource circulation in the regional economy, and enabling or partnering with actor groups to support urban gardening. While these measures seal a share of the phosphorus in the greenery, they reduce the spike in the water volume to be treated during heavy rainfall events. This reduces the amount and concentration of phosphorus in spill-overs from the sewers into the environment and avoids nutrient pollution. Simultaneously, the reduced pressure on the water infrastructure supports recycling efforts in sewage treatment plants.

A mix of all six modes of governance can overcome the challenge of incorporating private sector actors, from inhabitants to companies, into a local phosphorus policy. As suggested by experts and inspired by the new European FPR, a regional eco-label could be created. This would certify and reward phosphorus-sustainability supporting business practices, e.g., for the application of organic instead of mineral fertilizers. With this innovative instrument of public governance, the institutions would appear in the role of facilitator, issuer of the label, and information surrounding it to experiment with voluntary compliance. Experimentation is a viable instrument, considering the pool of innovative technologies to be activated for local phosphorus flow adjustments. Farmers and other private actors have a limited capacity and willingness to bear risks, rendering public institutions as pioneers that can provide leadership while opening opportunities for voluntarism. Self-governance can be applied in many cases and is, thus, an important tool for implementation. The significance of self-governance adjustments is supported further in the case study as The Hague is the capital city of The Netherlands, hosting the Dutch national government and a large public sector, employing the largest share of the region's workforce (17\% in 2017).

\section{Discussion}

Based on the case study of The Hague and Delfland, we found that local strategic phosphorus planning is locally feasible and, if framed properly, internationally meaningful. For municipalities in Western Europe and similarly democratic, decentralized contexts, it is chiefly the constitutional right to self-administration that allows public bodies to tap into a range of steering options. Using various modes of governance, they can either incentivize, regulate, or provide for local measures. These measures can directly impact phosphorus flows towards a selected goal. It is not the existence of specific public authorities, such as water boards, that determines the feasibility of local strategic phosphorus planning. 
An overarching strategic plan should consist of a holistic problem framing, a target, and be based on a transparent inventory that provides thorough knowledge of the local conditions. A mix of instruments, such as binding regulation, self-governance, and soft modes, can facilitate effective steering of flow-adjusting measures. Targets and measures can be voluntary or become obligatory in the form of partnerships or regulation, e.g., on recovery rates in wastewater treatment and incineration. The complete overview of recommendations is compiled in Table 3.

Table 3. Overview of transferable recommendations for strategic local phosphorus planning.

\begin{tabular}{|c|c|}
\hline Key Recommendation & Suitable Suggestions \\
\hline $\begin{array}{l}\text { Build capacity of public } \\
\text { administration at all levels for }\end{array}$ & $\begin{array}{l}\text { - } \\
\text { - } \quad \text { policieamlining recycling, food, and other substance } \\
\text { - } \quad \text { a long-term and large-scale perspective } \\
\text { - } \quad \text { leading by example in local resource planning } \\
\text { - } \quad \text { available governance instruments from soft } \\
\text { to regulatory }\end{array}$ \\
\hline Collaborate & $\begin{array}{l}\text { - with research and city networks to facilitate outreach } \\
\text { of knowledge } \\
\text { with researchers to investigate unintended side-effects, } \\
\text { synergies, and flow modelling gaps, quantitative } \\
\text { impacts of measures } \\
\text { across spatial and legal administrative boundaries to } \\
\text { facilitate measures and link producers with consumers } \\
\text { (e.g., investigate the needs of local producers and other } \\
\text { stakeholders for shared strategic local } \\
\text { phosphorus planning) }\end{array}$ \\
\hline
\end{tabular}

- $\quad$ use substance flow analysis as a decision support tool to identify key flows

- $\quad$ incorporate transparency and reporting requirements

Improve data into operation and management contracts for public private partnerships

- $\quad$ build an inventory and share information on local flows as open data

Increase export, decrease import and minimize losses of surplus phosphorus
- make transportable carrier materials available (i.e., dried \& concentrated)

- $\quad$ encourage dietary change to flexitarian diet

- $\quad$ offer locally produced fertilizer substitutes for mineral fertilizer

- $\quad$ increase locally sourced food supply (e.g., in canteens, create spaces for local food markets)

- $\quad$ reduce food waste in households and retail

- avoid nutrient release/dispersion into the environment (e.g., switch to separated sewer systems)

- $\quad$ avoid sealing of nutrients (e.g., in road filling of incineration ash)

- $\quad$ increase nutrient capture from both, wastewater, and solid waste

\subsection{Feasibility of Local Strategic Phosphorus Planning}

Public governance at the local scale can play a key role in leading into local resource planning. Dutch water boards demonstrated practicability by pioneering experiments and innovative approaches in testing nutrient recapture, e.g., in Leiden and Amsterdam. Awareness of future phosphorus scarcity risks prompted the water boards to explore local 
and global nutrient recycling, but their practical efforts lay dormant due to the lack of economic feasibility and a non-supportive regulatory context.

A challenge in the regulatory context comes from administrative boundaries that can be difficult to overcome. In terms of closing the phosphorus loop locally, they were more relevant than a spatial disconnect that limits circulation between recovery and agricultural production, as in the case described by Harder et al. (2019) [37]. Boundaries to the public scope for action characterize administrative boundaries and determine the governance potential of local authorities. They are limited in their reach and have no legal power over private actors or consumer decisions.

The disconnect between producers and consumers is entrenched by a physical, but not spatial, separation. The urban metabolism perspective shows the closed system design of horticultural greenhouses. They are optimized for productivity and minimize any exchange of flows (i.e., water or fertilizer) with the immediate surroundings. This creates a controlled environment for food production, as well as for waters exposed to agricultural run-off. However, this system excludes the application of most locally available types of organic fertilizers and requires specialized, reliable inputs to operate. An example is the experimental fertilization of open flower fields with iron-sand that is not feasible under the horticultural conditions.

With collaboration, informed local planning for strategic action could relink producers and consumers-a gap outside the scope for action of either of the two groups. Overcoming the challenge of a spatial, physical, and administrative disconnect for phosphorus circularity requires bridging across boundaries. While the linkage of urban and rural phosphorus flows is desirable [38], the case study showed the partial success of and the need to strengthen cooperation between the respective realms of public governance across spatial and administrative mandate boundaries. By strategically planning for the business case for phosphorus recovery from incineration ash, the public governing body demonstrated the opportunities that lie in cooperation with private actors, while being aware of the remit and motivation of the parties involved.

For collaboration on national and supra-national levels, cities could enter into established city networks. These networks could facilitate the outreach required for mitigation [35]. By advising urban decision-makers, city networks could integrate science-backed guidance on strategic phosphorus planning from active research platforms, e.g., the European Sustainable Phosphorus Platform. Moreover, under a wider umbrella, learnings from climate governance could be applied to record and stimulate sustainable phosphorus initiatives bottom-up. An example that integrates private actors is the platform for non-state actors, the so-called Non-State Actor Zone for Climate Action (NAZCA).

Local decision-makers should consider their large-scale impacts to ensure policy success and avoid repercussions of cumulative policymaking for "ecological overshoot and ecological collapse" [39], but they need better information in order to do this. This study confirmed that data on solid and fluid organic waste streams is fundamental for appropriate policy design and needs to be made available. This helps in terms of forecasting impacts, creating business cases for recovery options, tracking progress for policy adjustments, and general accountability of the sectors involved. Severe gaps in essential data on the regional metabolism present challenges for tailoring the optimal public policy solution. Reported data enables policy design based on reliable knowledge of the urban metabolism [40].

In order to build an inventory of flows, public governance should oversee and ensure reporting on all major phosphorus carrier flows. The availability of data on water-borne phosphorus flows in the case study area reflects the level of institutionalized and vertically well-integrated environmental protection. Private actors and public-private partnerships should be made transparent by incorporating reporting requirements into operation and management contracts in line with commercial confidentiality. These contracts typically last for several decades, creating a lock-in for public governance.

In tracking local flows in the inventory, the phosphorus flow analysis can be an effective decision-making support tool. It may require a large amount of data and is 
prone to data insecurities due to unknown factors, e.g., the quantity of food supply chain losses, reliability of the data sources used, and accuracy of dietary assumptions and matching of trade categories. However, despite the limitations of the substance flow analysis with its import-export expansion, it identifies path dependencies and supports prioritizing flows. Visualizing the phosphorus flows systematically reveals cascading effects and trade-offs between measures as they change conditions for any infrastructure downstream, including the economic viability for potential phosphorus recovery. Key flows to be addressed become clear because the phosphorus flow analysis pairs the carrier flow properties of phosphorus concentration with mass flow quantities. On the one hand, this allows seemingly insignificant material flows that may, overall, transport a sizeable total amount of phosphorus to be noted. This is of relevance for minimizing local eutrophication (e.g., sewerage overflows). On the other hand, large mass flows with a low total phosphorus content should not be prioritized for phosphorus recycling efforts, as the difficulty of recapture is linked to concentration and dispersal (e.g., drinking water supply). These aspects underscore the suitability of the application of industrial ecology methods to complement governance assessments [41].

\subsection{Impact Potential of Local Strategic Phosphorus Planning}

The study shows that strategic local phosphorus planning in the case study region has the potential to meaningfully address phosphorus flows. Local level planning, meaning in this case The Hague and Delfland, can alleviate the eutrophication of local water bodies, reduce scarcity and risks related to food security, as well as respond to the environmental injustice in current phosphorus supply.

Strategic local phosphorus planning can significantly impact phosphorus flows beyond local boundaries up to the global level. A rough estimate of the cumulative impact of all measures captured in the policy grid shows that the environmental pressure from eutrophication and on Planetary Boundaries can be alleviated. Based on the case study values, a rough international estimate of all urban areas combined could harvest enough phosphorus to substitute about $8 \%$ of the chemical fertilizer required for global agriculture [42]. The impact of the policy scenario of cumulative implementation of all available substance flow adjusting measures contributes to a future-proof phosphorus metabolism that respects concerns of potential scarcity as well as abundance.

Moreover, a cumulative implementation scenario of the proposed measures would create socio-economic and environmental benefits. The measures increase market-based phosphorus exports from the region to offer locally trapped phosphorus back to the world markets as recaptured fertilizer and in agricultural produce. Both can re-enter foodproducing countries and be utilized to replenish their soils. This represents a first step towards closing the phosphorus loop globally. The phosphorus flow analysis in the case study shows that about $40 \%$ of the phosphorus entering the system via food alone could be offered on the international market as high-grade fertilizer, recovered from incineration ash of sewage treatment sludge.

The major agrarian export countries with a negative phosphorus trade balance would benefit from a return of the resource. Among the food trading partners of The Netherlands, China, India and the African states, in particular, have recycling potential [37]. Their soils would be likely to profit from a regional phosphorus policy in The Netherlands that would reduce phosphorus withdrawal via food trade with the consuming country.

Despite the limitations of the import-export expansion in the local phosphorus flow analysis, the net withdrawal of phosphorus for some of the countries listed, especially Brazil, is confirmed by the recent research. Li, Wiedmann, and Hadjikakou (2019) [43] found a highly uneven distribution of phosphorus-compromised nations with China, Brazil, India, and New Zealand experiencing the largest losses. All of these countries are to be found within the list of Dutch trading partners experiencing phosphorus withdrawal via food products (Table 2). 
Globally, agricultural production, eutrophication, food export and phosphorus withdrawal can be directly influenced by local strategic phosphorus planning, as they appear to be closely linked. This becomes obvious as the same phosphorus-compromised nations are among the phosphorus emission hotspots exceeding the respective planetary boundary [6]. This direct connection enables socio-economic and environmental benefits far beyond the local level that may implement demand-side measures, rippling upstream along the supply chain. This indicates, in principle, significant potential for improvement in phosphorus sustainability via trade relations by moderating food imports and increasing nutrient returns via exports. A local strategic phosphorus plan should consider measures that address regional food production and trading.

Any agriculturally productive and largely exporting country would benefit from its own local strategic phosphorus planning by linking its cities and food production to alleviate dependency. In infrastructurally weak areas, this would reduce pressure on farmers who are disadvantaged by higher fertilizer prices [44]. In the case study area, the nearby cities and the closed system of the industrialized horticulture could be linked by recovering suitable, fluid fertilizers, e.g., from fermentation instead of composting. According to the local phosphorus flow analysis, this would tap the mostly unused but significant potential of organic waste streams for phosphorus capture and agricultural supply. While infrastructurally well developed, regionally-sourced fertilizer could be a locational advantage.

Locally recovered fertilizers would replace a share of the phosphate rock-based fertilizer consumed by industrialized agriculture, thus reducing mineral phosphorus imports. This contributes further to alleviating associated socio-economic and environmental sideeffects in global hinterlands.

Additionally, local strategic phosphorus planning can slightly decrease virtual phosphorus imports via food products without infringing consumer choices. Reduction measures targeting phosphorus-intensive food products as well as the overall amount of food consumed could ease pressure on the hinterlands and trading partners to a significant degree. Derived from the substance flow analysis of the metabolism of the region (Figure 2), the relevance of such demand-side measures is highlighted despite their challenging-but not impossible-governance implementation: If the food imports could be reduced by only ten per cent in the case study region, an amount of phosphorus equivalent to the local emissions into the North Sea ( $150 \mathrm{t}$ P/yr) could be saved. Public governance could support this by increasing the spaces dedicated to and improving the facilities provided for local markets or by consciously choosing locally sourced products for the canteens, especially in the growing public sector of The Hague. A switch of consumer behavior to a flexitarian diet as suggested by Forber et al. (2020) [45] as the least phosphorus straining option for the future, should be advocated. Moreover, the feasibility of looping the food supply for a major western European city to cover demand by local agriculture has been illustrated by Joseph et al. (2019) [46]. Not only would this contribute to staying within the planetary boundary, but also to supporting regional water safety governance efforts as phosphorus concentrations in freshwater bodies in and around The Hague were high. A change in household consumption would affect its environmental impact and can be linked quantitatively to the Sustainable Development Goals [47].

However, a local phosphorus plan should not focus on demand-side measures alone but always integrate end-of-pipe recovery. Based on the local phosphorus flow analysis, matching the recovery potential of sludge ash with demand-side measures would require a $44 \%$ reduction in food imports. Given the steadily growing population count in the area, it is not possible to reduce the overall food consumption to this extent. Instead, we learn from the variables that were used to compute the phosphorus amount in food imports that feasible reduction potential lies in targeting retail losses (11\%) and food waste (about $40 \%$ ). 


\subsection{Further Development of Local Strategic Phosphorus Planning}

Local decision-making should take on a long-term perspective that accounts for the governmental responsibility for the well-being of their citizens to build political will and awareness across different levels. This means looking beyond immediate concerns for public health and recognizing future threats to food security by considering food supply from urban hinterlands. The European Union leads the way towards this goal by founding a Global Alliance on Circular Economy and Resource Efficiency that will evaluate polices in countries outside the EU to remove obstacles to circularity.

With the EU Green Deal, the evolving legal context on the European level is opening up opportunities for local actors in phosphorus governance to turn waste into resources. As one of the building blocks of the European Green Deal, the European Commission adopted a renewed Circular Economy Action Plan in March 2020 [16]. The EU Circular Economy Package addresses the core issue by stipulating the re-evaluation of several EU directives, such as the Sewage Sludge Directive that regulates sludge applications in agriculture or the Fertilizing Products Regulation.

The draft EU Circular Economy Fertilizing Products Regulation (EU 2019/1009) aims to foster the use of organic and waste-based fertilizers. Due to come into force in 2022, it is planned to counteract the disadvantage of organic fertilizer products due to their legal status as waste, limiting their export. The new legislation is likely to strengthen market-based recycling and exports of phosphorus as it will enable the trading of organic fertilizers on the European market from 2022 onwards [17]. It facilitates improved access to EU markets with a combination of hard and soft approaches. The Fertilizing Products Regulation links policies in the water-soil nexus and the solid waste-related circular economy. It limits heavy metal pollution at $60 \mathrm{mg}$ cadmium $/ \mathrm{kg}$ of phosphorus pentoxide and incentivizes producers to apply fertilizer with less than $20 \mathrm{mg}$ cadmium $/ \mathrm{kg}$ of phosphorus pentoxide with a low-cadmium label $[40,48]$. As reserves of lesser quality are being mined, lowering of both limit values will reduce the imports of mineral phosphorus fertilizer which contain increasing concentrations of heavy metals and which compete with locally produced, organic fertilizer.

More and more political bodies at all levels are taking steps towards sustainable phosphorus management and will encourage local strategic phosphorus planning. Internationally, no established governance mechanism focusses specifically on phosphorus as yet, but the UNEP established the Global Partnership on Nutrient Management [12]. Aware of its lack of self-sufficiency in terms of phosphorus supply and its major import dependency [13-15], the European Union will develop an Integrated Nutrient Management Plan to ensure more sustainable use and recovery of nutrients. On a national level, several countries, including Switzerland and Germany, have enacted legislation that requires phosphorus recycling from wastewater.

Legal support or political will at all levels of public administration should explore synergies with other substance policies (e.g., for nitrogen, ammonia, and heavy metals) and create a nurturing environment to encourage local level ingenuity. They could facilitate options for shipment or domestic reuse of dried fertilizing by-products of sewage treatment or drinking water filtration processes which must be disposed of as waste. Established local motivation for emission reduction as well as circular economy can be expanded. If all policies around recycling and food were more explicitly streamlined, local strategic phosphorus planning could exploit their synergies, for example, via compost, high-grade fertilizers, and avoidance of mineral phosphorus imports. Since the case study region is an important player in terms of agricultural trade, these changes can contribute noticeably to environmental justice and phosphorus sustainability beyond the level to be expected from a medium-sized city. Extending urban priorities from carbon emission reduction to the synergies with phosphorus recovery could stimulate the diversion of organic matter to fertilizer production.

Further research should quantify the impacts of measures and tested governance interventions in order to prepare for implementation of local phosphorus policy. This means 
investigating unintended side effects, synergies, and flow modelling gaps. For example, this study omitted the footprint of animal feed in Delfland or biofuels. In particular, the latter will become increasingly important due to the Dutch Nationally Determined Contributions to the Paris Agreement which encourages their use [49]. This shortcoming may limit the suitability of suggested flow measures in the future.

Lastly, we encourage phosphorus governance researchers to communicate with decision-makers. Integrating local policy makers and stakeholders into the research process can significantly improve phosphorus research by providing in-depth insights into real-world contexts. In a transdisciplinary approach, both actor groups could develop research questions in collaboration in order to build local planning capacity and inform academic knowledge. As a beneficial side-effect, this enables researchers to disseminate discoveries into governance practices and advances into transformative science with local and far-reaching impacts.

\section{Conclusions}

This study demonstrated that strategic urban phosphorus planning is possible within Western municipal remits and can contribute to phosphorus sustainability locally and at various scales, up to the global scale. Across these levels, this study combined phosphorus metabolism research with governance analysis by mapping out factors, actors, and legal frameworks surrounding a case study on strategic resource management. A policy grid linked local phosphorus flows to steering measures to explore the urban potential to respect the planetary phosphorus boundaries.

The study showed that local phosphorus planning is feasible and meaningful under an appropriate problem framing. To frame the goals for urban phosphorus policy design, we propose that: local governance actors should focus on (1) eutrophication from nutrient pollution, (2) threats to food security due to phosphorus scarcity, and (3) environmental justice for global hinterlands. This integrated approach allows a broad range of locally available potential for implementation of flow measures across spatial and legislative boundaries to be tapped, with effects extending beyond the local level.

Finally, we encourage further research on the expression of strategic local resource planning in other cities. Testing the key recommendations and policy grid for policy development in different contexts will increase their validity.

Author Contributions: Conceptualization, L.H., C.Z. and B.S.; methodology, L.H., C.Z. and B.S.; software, L.H.; validation, L.H.; formal analysis, L.H.; investigation, L.H.; resources, L.H.; data curation, L.H.; writing—original draft preparation, L.H.; writing—review and editing, C.Z., L.H. and B.S.; visualization, L.H.; supervision, C.Z. and B.S.; project administration, L.H.; funding acquisition, L.H. and C.Z. All authors have read and agreed to the published version of the manuscript.

Funding: This research received external funding for the research stay in the Netherlands under the ERASMUS+ mobility program of the European Union. The current position of L.H. is financed by the Volkswagen Foundation's Freigeist Fellowship "Urban Footprints Project" by Cathrin Zengerling. The article processing charge was funded by the Baden-Württemberg Ministry of Science, Research and Art and the University of Freiburg in the funding programme Open Access Publishing.

Institutional Review Board Statement: Not applicable.

Informed Consent Statement: Not applicable.

Data Availability Statement: Not applicable.

Conflicts of Interest: The authors declare no conflict of interest. The funders had no role in the design of the study; in the collection, analyses, or interpretation of data; in the writing of the manuscript, or in the decision to publish the results. 


\section{References}

1. Ahlström, H.; Cornell, S.E. Governance, polycentricity and the global nitrogen and phosphorus cycles. Environ. Sci. Policy 2018, 79, 54-65. [CrossRef]

2. Withers, P.J.; Doody, D.G.; Sylvester-Bradley, R. Achieving sustainable phosphorus use in food systems through circularisation. Sustainability 2018, 10, 1804. [CrossRef]

3. United Nations Department of Economic and Social Affairs. Goals 11-Make Cities and Human Settlements Inclusive, Safe, Resilient and Sustainable. Available online: https:/ /sdgs.un.org/goals/goal11 (accessed on 4 July 2021).

4. Campbell, B.M.; Beare, D.J.; Bennett, E.M.; Hall-Spencer, J.M.; Ingram, J.S.I.; Jaramillo, F.; Ortiz, R.; Ramankutty, N.; Sayer, J.A.; Shindell, D. Agriculture production as a major driver of the Earth system exceeding planetary boundaries. Ecol. Soc. 2017, 22, 4. [CrossRef]

5. Rockström, J.; Steffen, W.; Noone, K.; Persson, Å.; Chapin, F.S., III; Lambin, E.; Lenton, T.M.; Scheffer, M.; Folke, C.; Schellnhuber, H.J.; et al. Planetary Boundaries: Exploring the Safe Operating Space for Humanity Space for Humanity. Ecol. Soc. 2009, 14, 2. [CrossRef]

6. Steffen, W.; Richardson, K.; Rockström, J.; Cornell, S.E.; Fetzer, I.; Bennett, E.M.; Biggs, R.; Carpenter, S.R.; Vries, W.D.; de Wit, C.A.; et al. Sustainability. Planetary boundaries: Guiding human development on a changing planet. Science 2015, $347,1259855$. [CrossRef]

7. Carpenter, S.R.; Bennett, E.M. Reconsideration of the planetary boundary for phosphorus. Environ. Res. Lett. 2011, 6, 14009. [CrossRef]

8. O'Neill, D.W.; Fanning, A.L.; Lamb, W.F.; Steinberger, J.K. A good life for all within planetary boundaries. Nat. Sustain. 2018, 1, 88-95. [CrossRef]

9. Conijn, J.G.; Bindraban, P.S.; Schröder, J.J.; Jongschaap, R. Can our global food system meet food demand within planetary boundaries? Agric. Ecosyst. Environ. 2018, 251, 244-256. [CrossRef]

10. Kisinyo, P.O.; Opala, P.A. Depletion of phosphate rock reserves and world food crisis: Reality or hoax? AJAR 2020, 16, 1223-1227. [CrossRef]

11. Cordell, D.; White, S. Life's Bottleneck: Sustaining the World's Phosphorus for a Food Secure Future. Ann. Rev. Environ. Resour. 2014, 39, 161-188. [CrossRef]

12. Nedelciu, C.-E.; Ragnarsdóttir, K.V.; Stjernquist, I.; Schellens, M.K. Opening access to the black box: The need for reporting on the global phosphorus supply chain. Ambio 2020, 49, 881-891. [CrossRef]

13. Yuan, Z.; Shi, J.; Wu, H.; Zhang, L.; Bi, J. Understanding the anthropogenic phosphorus pathway with substance flow analysis at the city level. J. Environ. Manag. 2011, 92, 2021-2028. [CrossRef]

14. Yuan, Z.; Wu, H.; He, X.; Liu, X. A bottom-up model for quantifying anthropogenic phosphorus cycles in watersheds. J. Clean. Prod. 2014, 84, 502-508. [CrossRef]

15. Metson, G.S.; Iwaniec, D.M.; Baker, L.A.; Bennett, E.M.; Childers, D.L.; Cordell, D.; Grimm, N.B.; Grove, J.M.; Nidzgorski, D.A.; White, S. Urban phosphorus sustainability: Systemically incorporating social, ecological, and technological factors into phosphorus flow analysis. Environm. Sci. Policy 2015, 47, 1-11. [CrossRef]

16. Goldstein, B.; Birkved, M.; Fernández, J.; Hauschild, M. Surveying the environmental footprint of urban food consumption. J. Ind. Ecol. 2017, 21, 151-165. [CrossRef]

17. Chowdhury, R.B.; Moore, G.A.; Weatherley, A.J.; Arora, M. Key sustainability challenges for the global phosphorus resource, their implications for global food security, and options for mitigation. J. Clean. Prod. 2017, 140, 945-963. [CrossRef]

18. Cordell, D. The Story of Phosphorus: Sustainability Implications of Global Phosphorus Scarcity for Food Security. Dissertation' Thesis, Linköping University, Linköping, Sweden, University of Technology, Sydney, Australia, 2010.

19. Rosemarin, A.; Ekane, N. The governance gap surrounding phosphorus. Nutr. Cycl. Agroecosyst. 2016, 104, 265-279. [CrossRef]

20. WBGU-German Advisory Council on Global Change. Humanity on the Move: Unlocking the Transformation Power of Cities; WBGU: Berlin, Germany, 2016; ISBN 9783936191455.

21. Seyhan, D.; Brunner, P.H. The choice of system boundaries for effective long-term management of phosphorus. J. Mater. Cycles Waste Manag. 2018, 20, 345-352. [CrossRef]

22. Weimer, D.L.; Vining, A.R. Policy Analysis: Concepts and Practice, 4th ed.; Prentice Hall: Upper Saddle River, NJ, USA, 2005.

23. Pica-Ciamarra, U. Basics in Policy Analysis: How Governments Should Design E Implement Policies; Columbia University: New York, NY, USA, 2009.

24. Birkland, T.A. An Introduction to the Policy Process. 1098-6596; Taylor \& Francis: Singapore, 2016. [CrossRef]

25. Mayring, P. Qualitative Content Analysis. In The SAGE Handbook of Qualitative Data Analysis; SAGE: London, UK, 2014; pp. 170-183. [CrossRef]

26. Gläser, J.; Laudel, G. Experteninterviews und Qualitative Inhaltsanalyse, 4th ed.; VS Verlag für Sozialwissenschaften: Wiesbaden, Germany, 2010.

27. Kalmykova, Y.; Harder, R.; Borgestedt, H.; Svanäng, I. Pathways and Management of Phosphorus in Urban Areas. J. Ind. Ecol. 2012, 16, 928-939. [CrossRef]

28. van Dooren, C.; Marinussen, M.; Blonk, H.; Aiking, H.; Vellinga, P. Exploring dietary guidelines based on ecological and nutritional values: A comparison of six dietary patterns. Food Policy 2014, 44, 36-46. [CrossRef] 
29. De Boer, M.A.; Romeo-Hall, A.; Rooimans, T.; Slootweg, J. An Assessment of the Drivers and Barriers for the Deployment of Urban Phosphorus Recovery Technologies: A Case Study of The Netherlands. Sustainability 2018, 10, 1790. [CrossRef]

30. Van Grinsven, H.; Bleeker, A. Evaluation of the Manure and Fertilisers Act 2016: Synthesis Report; PBL Netherlands Environmental Assessment Agency: The Hague, The Netherlands, 2017. Available online: www.pbl.nl/en (accessed on 4 July 2021).

31. Aloe, A.K.; Bouraoui, F.; Grizzetti, B.; Bidoglio, G.; Pistocchi, A. Managing Nitrogen and Phosphorus Loads to Water Bodies: Characterisation and Solutions: Towards Macro-Regional Integrated Nutrient Management; Joint Research Centre, JRC-Ispra: Luxembourg, 2014; ISBN 9789279400728.

32. Vigiak, O.; Grizzetti, B.; Zanni, M.; Dorati, C.; Bouraoui, F.; Aloe, A.; Pistocchi, A. Estimation of Domestic and Industrial Waste Emissions to European Waters in the 2010s; European Union: Belgium, Germany, 2018.

33. Van Waterschappen, U. Klimaatakkoord Unie en Rijk 2010-2020; “uitgever" (Dutch): The Hague, The Netherlands, 2010. Available online: https: / / www.uvw.nl/wp-content/uploads/2010/07/Klimaatakkoord-Unie-en-Rijk-2010-2020.pdf (accessed on 4 July 2021).

34. Bulkeley, H.; Kern, K. Local Government and the Governing of Climate Change in Germany and the UK. Urban Stud. 2006. [CrossRef]

35. Kern, K.; Albers, G. Governing Climate Change in Cities: Modes of Urban Climate Governance in Multi-level Systems. Urban Dimens. Clim. Gov. 2009, 171-196. [CrossRef]

36. Broto, V.C.; Bulkeley, H. Maintaining climate change experiments: Urban political ecology and the everyday reconfiguration of urban infrastructure. Int. J. Urban Reg. Res. 2013, 37, 1934-1948. [CrossRef]

37. Harder, R.; Wielemaker, R.; Larsen, T.A.; Zeeman, G.; Öberg, G. Recycling nutrients contained in human excreta to agriculture: Pathways, processes, and products. Crit. Rev. Environ. Sci. Technol. 2019, 49, 695-743. [CrossRef]

38. Trimmer, J.T.; Guest, J.S. Recirculation of human-derived nutrients from cities to agriculture across six continents. Nat. Sustain. 2018, 1, 427-435. [CrossRef]

39. McBain, B.; Lenzen, M.; Wackernagel, M.; Albrecht, G. How long can global ecological overshoot last? Glob. Planetary Chang. 2017, 155, 13-19. [CrossRef]

40. Fertilizer Product Regulation (2019/1009). Available online: https:/ / eur-lex.europa.eu/legal-content/EN/TXT/?uri=CELEX\% 3A32019R1009 (accessed on 4 July 2021).

41. Zengerling, C. Governing the City of Flows: How Urban Metabolism Approaches May Strengthen Accountability in Strategic Planning. Urban Plan. 2019, 4, 187. [CrossRef]

42. Chen, M.; Graedel, T.E. A half-century of global phosphorus flows, stocks, production, consumption, recycling, and environmental impacts. Glob. Environ. Chang. 2016, 36, 139-152. [CrossRef]

43. Li, M.; Wiedmann, T.; Hadjikakou, M. Towards meaningful consumption-based planetary boundary indicators: The phosphorus exceedance footprint. Glob. Environ. Chang. 2019, 54, 227-238. [CrossRef]

44. Cordell, D.; Turner, A.; Chong, J. The hidden cost of phosphate fertilizers: Mapping multi-stakeholder supply chain risks and impacts from mine to fork. Glob. Chang. Peace Security 2015, 27, 323-343. [CrossRef]

45. Forber, K.J.; Rothwell, S.A.; Metson, G.S.; Jarvie, H.P.; Withers, P. Plant-based diets add to the wastewater phosphorus burden. Environ. Res. Lett. 2020. [CrossRef]

46. Josephs, S.; Peters, I.; Friedrich, H. Can Regional Organic Agriculture Feed the Regional Community? A Case Study for Hamburg and North Germany. Ecol. Econ. 2019, 164, 106342. [CrossRef]

47. Scherer, L.; Behrens, P.; Koning, A.D.; Heijungs, R.; Sprecher, B.; Tukker, A. Trade-offs between social and environmental Sustainable Development Goals. Environ. Sci. Policy 2018, 90, 65-72. [CrossRef]

48. European Commission. Circular Economy: New Regulation to Boost the Use of Organic and Waste-Based Fertilisers; European Commission: Brussels, Belgium, March 2016. Available online: https://ec.europa.eu/commission/presscorner/detail/de/ MEMO_16_826 (accessed on 4 July 2021).

49. Hein, L.; Leemans, R. The impact of first-generation biofuels on the depletion of the global phosphorus reserve. Ambio 2012, 41, 341-349. [CrossRef] 